Twain's second comment occurred in a draft preface for A Connecticut Yankee in 1888: "Human liberty—for white people-may fairly be said to be one hundred years old this year [. . .]" (A Connecticut Yankee in King Arthur's Court [Berkeley: U of California P, 1977] 518). Race is at the forefront of Twain's chronology. The real source of discontent is that readers feel that Huck's determination to go to hell for his friend Jim should be followed by a breaking out. The absence of such a breakout and Twain's immersion of his characters in stupefying burlesque and caricature are certainly what antagonized a reader like Ernest Hemingway and later scholarly critics who describe the ending of the novel as "flawed." Yet such an outcome is foreshadowed by the ending of Adventures of Tom Sawyer, where Huck, the only speaker to use the word "nigger" in the last several chapters, says he is willing to eat with Uncle Jake, whom Huck identifies as "a mighty good nigger," as long as it is not generally known. Race and class issues are consciously, but unpleasantly, jumbled in Twain's satire, as they still are in American society; Twain's humor is confrontational, and so it brings disquiet to readers who are not properly prepared by experience, intrinsic insight, or good teaching. Great works by many other authors share this characteristic, as is easily proved by the line of freshman readers who appear at my desk to ask if Swift really thought eating babies would solve the Irish hunger problem. Twain's challenge, and ours, as Margolis suggests, is to get past our distress at having our "good intentions" exposed as hollow and to accomplish the social and economic conditions that make "human liberty" as Twain understood it-liberty from absolutist authority and also from economic repression—an actuality. Until then, any accurate reader should be discontented with the conclusion of Adventures of Huckleberry Finn, but as a work of fiction, the novel does its work brilliantly.

David E. E. Sloane University of New Haven
Reply:

Carl F. Wieck calls attention to one aspect of my argument about Huckleberry Finn: the connection between the forty dollars handed to $\mathrm{Jim}$ at the end of the evasion sequence and the Reconstruction promise to provide the freedmen with "forty acres and a mule." The first time I ever heard of Wieck's work was when $A N Q$ sent me his book (Refiguring Huckleberry Finn) to review_long after my essay had been accepted for publication by PMLA. I confess I was surprised by Wieck's letter, having just submitted a review praising Wieck for tracing structural patterns in the text, like the repetition of the number forty, that have hitherto gone virtually unexamined by critics. But my review also points out that, aside from mentioning the legacy of "forty acres and a mule," he makes no sustained argument about its significance in the novel. It's a shame that Wieck is so wedded to his "results" that he is oblivious to their implications.

Stacey Margolis University of Utah

\section{The Copyediting of Literary Manuscripts}

To THE EDITOR:

M. Thomas Inge opens his "Collaboration and Concepts of Authorship" (116 [2001]: 62330) by announcing that "[i]t is commonplace now to understand that all texts produced by authors are not the products of individual creators," that they are, in other words, products of "the collaborative process." He immediately adds, however, that "the romantic myth of the author as solitary genius" is a continuing and, in his estimation, an objectionable belief. But are not the two points merely the two sides of the same coin? If one is "commonplace," the other is or should be too. I mean to suggest that I have some trouble understanding the driving force behind Inge's article, which, I hasten to add, does lucidly exemplify various kinds of collaboration. In one way Inge's major and pertinent examples-The Waste Land, Sister Carrie, various works by 
Thomas Wolfe-leave me uneasy because they suggest that "the collaborative process" is always felicitous. Inge does not face the possibility that there are instances in which collaboration amounts to genuine interference and leads to distortions, even major ones. More important, I am troubled by Inge's hostility to textual critics who may attempt to erase one or more layers of needless collaboration. Though he acknowledges that "scholarly editions" contribute to some types of knowledge (about the "process of composition" and "working habits"), he concludes that such works "are not the books that were originally published, reviewed, read, and discussed by generations of teachers and critics. [...] They should not be assigned in classrooms to students unfamiliar with the original editions and the works' cultural contexts" (628). I am left wondering if here is really the debatable issue. Perhaps Inge's approach might have been modified if he had been more sensitive to the theoretical work of textual critics, especially to G. Thomas Tanselle's A Rationale of Textual Criticism (1989).

The question of collaboration concerns me primarily because of a single novel: Charlotte Brontë's Jane Eyre, an example very unlike those cited by Inge.

On 24 August 1847, when Charlotte Brontë mailed her manuscript of Jane Eyre, a beautifully clear fair copy, to Smith, Elder, she was an ambitious, unknown, and powerless woman, one who felt the need to hide behind a male pseudonym. Frustrated by repeated rejections of The Professor, suddenly surpassed by her younger sisters, who had novels scheduled for publication, and grateful to Smith, Elder for their courteous rejection of The Professor and then their rapid acceptance and printing of Jane Eyre, Brontë, it is reasonable to assume, would have done anything to avoid jeopardizing or even delaying the publication of her three-volume novel. On 24 September, probably the day on which she received her first proofs, she wrote the following to Smith, Elder: "I have to thank you for punctuating the sheets before sending them to me, as I found the task very puzzling, and, besides, I consider your mode of punctuation a great deal more correct and rational than my own" (The Brontës: Their Lives, Friendships, and Correspondence, ed. Thomas J. Wise, vol. 2 [1933; Philadelphia: Porcupine, 1980] 142). A few days later (29 Sept.), in a brief note probably written when she returned the first proofs, she again thanked Smith, Elder for their "attention in punctuating the sheets" (143). Before evaluating these statements, we need to realize that the fair copy of Jane Eyre is fully punctuated, in what I call a grammaticalrhetorical mode (of course, with some quirks and inconsistencies) and in what others have called a "light," "informal," and "expressive" manner. Moreover, the "heavy," the incredibly "heavy," punctuation supplied by the Smith, Elder compositors is so bewildering, so perversely inconsistent, that for all practical purposes it is the opposite of "correct and rational." According to my counting and estimating, the compositors made a minimum of ten thousand changes in Charlotte Brontë's accidentals, mostly changes in punctuation. The procedure was not merely one of substituting "heavier" marks for "lighter" ones (say, semicolons for commas): the compositors took various liberties, such as changing the length of sentences - that is, sometimes combining several short sentences into one period and sometimes splitting long sentences into several shorter ones. (What an outcry there would have been if works by Joyce or Faulkner had suffered the kind of collaboration forced on Charlotte Brontë!) Admittedly, a few of the compositors' changes clarify the text, but the vast majoritythousands and thousands - are totally arbitrary. With this context in mind, today we could read Brontë's thank-you notes as sharply ironic; more likely, however, her statements are the startled acquiescence of a powerless woman. Given that the fair copy remained in London while Brontë examined the proofs and that she realized that changes in proofs could cost time and money (The Brontës 85), she had no alternative but to accept, humbly, the collaboration of the Smith, Elder compositors, whose names (George Dyer Wilson, D. Ross, W. Beck, Kemp, et al.), by 
Inge's standards, probably should be listed on the novel's title page. Only in very insignificant ways was she ever able to restore the punctuation of her manuscript.

Modern editors of Jane Eyre, taking Brontë's letters of 24 and 29 September as a clear statement of intention, have made the grave mistake of using the first edition rather than the fair copy as their copy-text, as Bruce Harkness decisively argued in a review of the Clarendon edition (Nineteenth-Century Fiction 25 [1970]: 355-69) and as I exemplified in my "Pointing Theory and Some Victorian Practices" (Yearbook of Research in English and American Literature 4 [1986]: 97134, esp. 114-22). The result is that all readers except the few who have studied the manuscript have seen Charlotte Brontë or Jane Eyre (to borrow Inge's analogy) attired in the most grotesque Victorian garb imaginable and not in the relatively simple, neat, and appealing frock supplied by the author. Indeed, the thousands of changes made to the fair copy (Inge illustrates how a single comma can be noteworthy) do accumulate in importance and do help to govern tone, emphasis, pace, and certainly nuances.

Though I am not prepared to cite other instances like Jane Eyre, I suspect that the novel is not an anomaly and that other texts are equally in need of decollaboration. In any case, Charlotte Brontë, no longer obscure and powerless, deserves the kind of collaboration that she could not command in 1847 . I would welcome an experienced editor who could collaborate with me to give the world the Fair Copy Edition, a readable edition suitable for both scholars and students.

Daniel P. Deneau Fairhope, AL

Reply:

Daniel P. Deneau makes many sound points. It is not my intention, however, to suggest that the collaborative process in publishing that I describe necessarily benefits works of literature. As I note, “It doesn't always work this way, but it works often enough to have made some publishing firms financially solid and some authors wealthy" (625).

The case of Jane Eyre is an exceptional one that I doubt is widely representative, and if things are as bad as Deneau suggests, one wonders why Charlotte Brontë so freely acceded to the punctuation provided by the publisher. She may have been an "unknown [...] and powerless woman," but did she have to be so enthusiastic? It is true she was not in the position of Mark Twain, who owned his own publishing firm and could wire the managing editor about preparing A Connecticut Yankee in King Arthur's Court for publication, "[Y]esterday Mr. Hall wrote that the printer's proof-reader was improving my punctuation for me, \& I telegraphed orders to have him shot without giving him time to pray" (A Connecticut Yankee in King Arthur's Court, ed. M. Thomas Inge [Cambridge: Cambridge UP, 1997] xix).

It is interesting to note what Deneau calls for at the conclusion of his letter-someone with whom to collaborate on a new edition. A lot of important things do seem to get done most easily with more than one hand at work.

M. Thomas Inge Randolph-Macon College

\section{The Tone of Debate in the Forum}

\section{TO THE EDITOR:}

Your concern with the paucity of quality submissions to PMLA finds a partial response in Linda Hutcheon's timely Presidential Address (116 [2001]: 518-30), in which Hutcheon and other scholars explore alternatives to the "adversarial academy." I suggest that PMLA itself appears as a particularly adversarial forum, discouraging many, particularly junior, scholars from sending you articles.

Some of the letters that are published in the PMLA Forum exhibit the very culture of negative critiquing to which Hutcheon tries to find alternatives. We all know that destructive opposition can make or break professional identities and on occasion do lasting damage to the "loser's" con- 